\title{
SWOT Analysis of Risk Communication during COVID-19 Responses in Ethiopian Higher Educations
}

Mekonnen Hailemariam Zikargae ( $\sigma$ mekozikargae@gmail.com )

Bahir Dar University

\section{Research}

Keywords: Ethiopia, Higher Education, risk communication, COVID-19

Posted Date: November 24th, 2020

DOl: https://doi.org/10.21203/rs.3.rs-113000/v1

License: (a) (1) This work is licensed under a Creative Commons Attribution 4.0 International License. Read Full License 


\section{Abstract}

Background: this study aimed to evaluate the risk communication regarding COVID-19 preventions in Ethiopian higher education institutions. Ethiopia is one of the 213 countries which affected by COVID-19. Since it appeared in the country different risk responses are underway to minimize the impacts in different sectors of the country. Ethiopian higher educations are among those sectors that are affected by the pandemic. Universities engaged as a task force in the response process. Universities are engaged in the national response scheme. Every attempt to risk communication is an endeavor to tackle the impact that transcends across the globe.

Methods: the study used the Strengths, Weaknesses, Opportunities, and Threats analysis on the experiences of Ethiopian higher education, task force, risk communication response to COVID-19 pandemic since the announcement of the outbreak by WHO as a pandemic. The government put a huge effort in risk communication to reduce the impact of COVID-19. The data sources include research conducted by the university staffs, risk communication working papers prepared to the Ethiopian contexts, different websites and media sources were used. Web-search approach used to gather most important performances and challenges of higher education.

Results: the findings show that higher education as a task force contributed to the national efforts based on research, humanitarian assistance, online meetings, E-learning and conferences. Research conducted focused on KAP's. There were no clinical based research. The research by academicians are almost nil. E-learning is developed to support disrupted higher education in Ethiopia. Thus, postgraduate could be facilitated out of the campus through E-learning. However, the E-learning has the weakest to support undergraduate and even the postgraduate programs. Internet infrastructure and acculturation of students' E-Learning are problematic.

Conclusion: the total effort of risk communication at Ethiopian higher education is minimal and not well organized. The challenges are the remaining home works to the universities. I suggest that risk communication strategies and research based solutions have to be evaluated and revisited to curb the impacts of COVID-19 in higher education.

\section{Background}

Following the communication of the outbreak of pneumonia caused by a novel, coronavirus began, December 2019, in China Wuhan; the world started to develop different strategies of risk communication, prevention, and control mechanism and tasks. The World Health Organization (WHO) announced, on January 30, 2020, that COVID-19 is a public health emergency of international concern. Since then the coronavirus COVID-19 is affecting 213 countries and territories around the world and two international conveyances. Until the beginning of August 2020, coronavirus cases and deaths reported $(18,270,654 \& 697,555)$ respectively. There are 11,467,762 million people recovered and survived. Similarly, in Ethiopia, 18,706; 310; 7,601 coronavirus cases, deaths, and recovery are reported respectively. Likewise, following the WHO endorsement of the pandemic, the Ethiopian government officially, in its risk communication strategy, announced and closed all types of educational institutions on 16 March 2020 to curb the possible impacts of COVID-19. Ethiopia declared a state of emergency to curb transmission of coronavirus on 14 April 2020. The Government declared a 5-month state of emergency in an effort to limit the spread of the COVID-19 through banning and restricting movements and activities. All sorts of communication activities during the outbreak are essential to the management of the outbreak. Risk communication in this regard is a pro-active communication that is necessary for an effective response to a real or potential health threat. Risk communication is a pro-active communication that encourages the public to adopt protective behaviors, facilitates heightened disease surveillance, reduces confusion, and allows for better use of resources [1]. This paper explores risk communication as a pro-active communication strategy of response used in Ethiopian higher education institutions as one of the task force to curve the impact of COVID-19. In addition, the paper outlines the major risk communications used during the crises. Further, the paper identifies the major challenges to combat COVID-19 [2]. More than 1.5 billion students and youth across the planet are affected by school and university closures due to the COVID-19 outbreak.

\section{Risk Communication}

Effective risk communication at both individual and public levels can play a key role in relation to reducing the negative influence of risk factors. It can be used to improve ways of communicating risk information. Risk communication could be in a better position due to the emergence of new technologies. Reliable and credible information are key factors to effectively communicate risks. Thus, risk communication is an ongoing communication process that addresses knowledge, attitude, perceptions, and behaviors related to risks. It can be applied to information and communication; stimulating behavior change and taking protective measures; issuing of disaster warnings and emergency information; and exchange of information and a common approach to risk issues [3]. Risk reduction is at the center of risk communication. If not well handled, risk communication is complex and could have an impact on the audiences (Fig. 1).

It is finding a comprehensive way of presenting complex risk issues. In risk communication mass media plays an important role to exchange reliable information of risks between the communicator and the audiences. Here, most risk communications are two-way

Page 2/13 
communication that builds up a consensus between the communicators. In a two-way process, trust and credibility are the fundamental components of risk communication [4].

\section{Continuum of Risk Communication}

WHO defines risk communication as "a dynamic process of sharing \& responding to information about a public health threat" [5]. Besides the essence of its definition, WHO developed a continuum of 5-steps of risk communication (Fig. 1) to curb a public health threat like COVID-19.

\section{SWOT Analysis}

SWOT analysis as a scientific approach provide us with a lens of window to look at the different perspectives where an organization could function as an open system. As organization is working in a dynamic environment, there could be factors that hinder or facilitate its performance. The internal situations of the organization could coexistent to its external situations. Both situations from inside and outside have the power to shape the culture and performance of the organization. Ultimately any alter from inside and outside shapes an organization. Thus, SWOT analysis help a researcher to come up with those dynamics of the organization.

\section{Methodology}

The target study subject of the current study is higher education institutions. SWOT analysis is a type of study and an analytical tool used to evaluate the risk communication to curb COVID-19 impacts by the Ethiopian Higher educations. The data was collected based on websearch, Google search. Evidence-based analysis had been undergone. Accordingly, in this analysis I attempted to evaluate the strengths, weaknesses, opportunities, and threats to combat the pandemic. SWOT analysis as a methodology aims to identify the internal and external factors that may affect desired future outcomes. Ethiopian higher education was primarily the source of the analysis. I engaged in deep-dig of data mining based on the available literature to form the SWOT analysis. Besides, different documents were also explored online. In this search published research done by Ethiopian higher education academics were collected. I categorized those articles into their types of research, authors' affiliation, study areas, participants, instruments, finding and suggestions for improvement (Table 1). In addition relevant documents are categorized into theme. The analysis done based on thematic or categories of the COVID-19 responses. It involves specifying the objective of the taskforces and identifying the internal and external factors that are favorable and unfavorable to achieving the task force objective. The study period for the current research could be Feb-Aug 2020 . In summary, I specifically presented the data gathered for SWOT analysis using tables (Table 1 \&2). In the rest of the presentation I used diagrams and graphs (Fig. 1-6).

\section{Results And Discussion}

\section{Background of the Pandemic, COVID-19, in Ethiopia}

The world is in turmoil due to non-weapon impacts of COVID-19. COVID-19 severely heated the social, political, economic and environment of the globe. The researchers of COVID-19 compare the pandemic with the Second World War [6]:

The recent outbreak of COVID-19 is the worst global crisis after the Second World War. Since no successful treatment and vaccine have been reported, efforts to enhance the knowledge, attitudes, and practice of the public, especially the high-risk groups, are critical to manage COVID-19 pandemic.

The status of the COVID-19 is manifested through a summary of total cases, daily cases, and total deaths in the following figures [Period: Feb and Jul 2020] (Fig. 2, 3, 4)Ethiopian government took several preventive measures both at community and individual levels. At the community level, the imposed preventive measures are shouting down schools, suspending sporting events and public gatherings; suspending flights to several countries; and introduced a mandatory self-quarantine for 14 days on arrival from abroad. Besides, at the individual level preventive measures are hand washing; avoiding handshaking and contact with others; social distancing; maintaining respiratory hygiene; wearing masks for health workers and infected groups, and isolation after infection or suspicion for infection.

However, studies indicated that the relevance and feasibility of both individual and community level measures heavily depend on how the public perceived the risks and impacts of being infected with the virus [7]. The indicators of the above-mentioned efforts have been kept a low opportunity window to prevent the pandemic. Since March 2020 only 6 deaths out of a population of 109 million by COVID-19. This is a rewarding achievement even if it requires more stemming and endeavors.

\section{Risk Communication Strategy Development: Ethiopian Perspective}

The Ethiopian government has responded swiftly and boldly to the COVID-19 crisis. 
The government initially well communicated the outbreak by providing public health COVID-19 prevention strategies to aware of the public. Besides, the Ethiopian government went through a terrain of major tasks of risk communication: (1) strictly followed house to house screenings, diagnostic tests, encouraging production and economic activities to continue during the crisis; (2)the Ethiopian authorities have implemented a strict regime of rigorous contact tracing, isolation, compulsory quarantine, and treatment.

Further, the task forces are arranged for the public universities' dormitories to increase the capacity of quarantine centers. Above all, the Ethiopian government has relied heavily on community mobilization and public-awareness campaigns. Therefore, the government ensured a coherent and patterned public health prevention response by maximizing coordination among public universities at different levels. However, the Ethiopian government COVID-19 strategies must reflect and dependent on the local context, the evolving nature of the pandemic, binding resource constraints, and weak international collaboration.

Combating an outbreak needs to arrange a well-established system to communicate the risk. Risk communication is a pro-active communication tool which helps to make rapid public health response. One of the most important risk communication system development is to organize hierarchical responsible bodies from different and in different organizations. According to WHO guideline [5] it is possible to avoid miscommunication, confusion and increase protective behaviors "by alerting a population and partners to infectious disease risk, surveillance of potential cases increases, protective behaviors are adopted, confusion is limited and communication resources are more likely to be focused". In the aftermath of the close of educational systems, the government arranged a task force for mobilizing the stakeholders towards combating the impacts of the COVID-19. One of the task forces is the Ethiopian higher education sector, Ministry of Science and Higher Education (MoSHE) COVID-19 taskforce (Fig. 5). MoSHE is responsible to communicate with as well as lead and mobilize science, higher education as well as the technical and vocational education and training (TVET) in Ethiopia. The task force also arranged Higher Education Institutions (HEI)-as HEl-levels tasks. Under the umbrella of MoSHE, 45 universities are containing one million students. These universities were communicated by MoSHE and the universities returned all students to their family before the state of emergency. The following figure (Fig. 5) manifests the universities as the major sector to participate in the national COVID-19 task-forces. Their roles during the pandemic also briefly stated in the areas of research and community services.

\section{MoSHE's risk communication during the COVID-19}

There are different strategies of risk communication developed by HEl during the COVID-19. One of the strategies is to establish a task force in Ethiopian higher education where the university's top management establishes a task force at university levels. The other important risk communication during the COVID-19 is to develop a webinar for discussions, meetings, and seminars. MoSHE, for instance, communicated through a webinar developed for the promotion of scientific research in Africa facing the COVID-19 to share the Ethiopian experiences (Fig. 6.)

The objective of the webinar was to share national scientific research activities on COVID-19. It could be one of the examples of developing a webinar to connect higher education officials. Similarly, the Ministry held different online VIRTUAL meetings with top management of the universities' decision-making on the current and prospects of the higher education research, community service, and teaching-learning processes.

\section{Media during Risk Communication}

The new digital era increased ease and accessibility to disseminate information and communicate with many people instantaneously through the utilization of these new technologies could become crucial in effectively communicating risk during a pandemic. On Friday, 13th February 2020, Ethiopia confirmed and communicated its first case of COVID-19 at the capital city, Addis Ababa. The government agreed to share information regarding COVID-19 activities that could be reported daily by the Ministry of Health via social media and the Ethiopian COVID-19 monitoring platform at www.covid19.et. However, the different mainstream media such as TV, Radio, and Newspapers are crucial in stemming the outbreak. They also entertained different sorts of communication using verbal and nonverbal communication like public health hand wash strategies. Moreover, universities and MoSHE risk communication strategies relied on webinars, emails, social media, telegrams, and virtual online communications. Scholars suggest that "one potential way to ensure appropriate risk communication is using social media channels, and ensuring an ongoing consistent media presence" [9]. This argument asserts that the requirement of broader public messaging is efficient to make effective risk communication during the outbreaks. However, this might be difficult to address people of developing countries like Ethiopia where the internet penetration rate is below $15 \%$. Besides, the assumption seems elusion to rural people where $80 \%$ of the population of Ethiopia is living. Those factors make risk communication infeasible in Ethiopia. This opportunity in Ethiopian higher education institutions could be somewhat mandatory to take preventive measures for those who are connected online.

\section{Higher Education Challenges and Responses: Global Higher Education Perspectives}


The international literature on COVID-19 and higher education is growing. I can found many global literature on "COVID-19 and higher educations" However, a previous survey report [10] on higher education challenges and responses to COVID-19 brought some findings in the middle, May 2020, of the study period of current research(Feb-Aug2020). It was conducted by international Association of Universities. It had monitored the impacts of COVID-19 on higher education around the world. The global survey report focused on the assesment of the impact of COVID-19 on research, teaching and learning, community engagment, students enrolment and partnership. Therefore, the finding of the report indicated that almost all HEls teaching learning affected the face-to face and turned into distance teaching and learning. Besides, the report indicated that mobility is everywhere negative. Moreover, $80 \%$ of HEls research affected by COVID-19.Further, COVID-19 weakened partnership. Most litrature forecasted its impact will remain up to the the disrubtion of the pandemic spread around the world. It has a multidimensional crisis that affect all of us.

\section{High Level Risk Communication: Ethiopian Perspective}

Ethiopia made the highest level of decision-making and the level of risk communication. Ethiopia declares the State of Emergency to curb transmission of Coronavirus on 14 April 2020. The Government declared a 5-month state of emergency to limit the spread of the Coronavirus (COVID-19). The state of emergency declared under the Proclamation 3/2020, also known as the "State of Emergency Proclamation Enacted to Counter and Control the Spread of COVID-19 and Mitigate Its Impact". Furthermore, the House endorsed a sevenmember State of Emergency inquiry board to scrutinize its implementation following the Constitution. There were different activities banned, restricted, and closed for five months of the state of emergency. All public gatherings: The ban applied to all religious, governmental, non-governmental, commercial, political, and social gatherings. The gathering is of a group of four people where individuals expected to ensure that they are 2 meters apart at all times. Different activities: greetings by handshake, land borders movement, passenger loads for all national and local journeys, reducing workforces, students and teachers meetings, and measures on social distancing, sporting activities, and children's playgrounds closed. Penalties: Any person failing to comply with these obligations will face up to three years imprisonment or a fine of between $£ 25.00-£ 5,000.00$.

\section{Research Based Risk Communication: University Perspective}

The researcher used key major terms to find research conducted in the Ethiopian context since the outbreak of the pandemic, COVID-19. The terms used to search were "knowledge”, "attitude”, "practice”, “COVID-19”, "pandemic", "prevention”, and "control”. Besides, other technical terms were used to explore the articles. Based on these search terms the researcher found five articles published from Feb-Jul 2020.These papers published by the Ethiopian higher education academicians. Almost all papers focused on Knowledge, Attitude, and Practices (KAP) study approach. Therefore, the articles are focusing on preventive and control methods of risk communication. The five articles thematic findings and respected suggestions are summarized as follows (Table 1). 
Table 1

COVID-19 research articles and their respective findings

\begin{tabular}{|c|c|c|c|c|c|c|c|}
\hline Author & Affiliation & $\begin{array}{l}\text { Type of } \\
\text { research }\end{array}$ & $\begin{array}{l}\text { Site of } \\
\text { research }\end{array}$ & Participants & Instruments & Study findings & $\begin{array}{l}\text { Researchers } \\
\text { suggestions }\end{array}$ \\
\hline Akalu,2020 & $\begin{array}{l}\text { University of } \\
\text { Gondar }\end{array}$ & $\begin{array}{l}\text { Cross- } \\
\text { sectional } \\
\text { study }\end{array}$ & $\begin{array}{l}\text { Addis } \\
\text { zemen } \\
\text { Hospital }\end{array}$ & $\begin{array}{l}\text { 404,chronic } \\
\text { disease } \\
\text { patients }\end{array}$ & questionnaire & $\begin{array}{l}\text { The prevalence of } \\
\text { poor knowledge } \\
\text { and poor practice } \\
\text { was high }\end{array}$ & $\begin{array}{l}\text { Leaflets } \\
\text { prepared in } \\
\text { local } \\
\text { languages } \\
\text { should be } \\
\text { administered } \\
\text { and health } \\
\text { professionals } \\
\text { should provide } \\
\text { detailed } \\
\text { information } \\
\text { about COVID- } \\
19 \text { to their } \\
\text { patients }\end{array}$ \\
\hline Kebede,2020 & $\begin{array}{l}\text { Jimma } \\
\text { University }\end{array}$ & $\begin{array}{l}\text { Cross- } \\
\text { sectional } \\
\text { study }\end{array}$ & $\begin{array}{l}\text { University } \\
\text { medical } \\
\text { center }\end{array}$ & $\begin{array}{l}247, \text { clents, } \\
\text { patients }\end{array}$ & exit interview & $\begin{array}{l}\text { The status of } \\
\text { knowledge and } \\
\text { desirable practices } \\
\text { were not sufficient } \\
\text { enough to combat } \\
\text { this rapidly } \\
\text { spreading virus. }\end{array}$ & $\begin{array}{l}\text { COVID-19 risk } \\
\text { communication } \\
\text { and public } \\
\text { education } \\
\text { efforts should } \\
\text { focus on } \\
\text { building an } \\
\text { appropriate } \\
\text { level of } \\
\text { knowledge } \\
\text { while } \\
\text { enhancing the } \\
\text { adoption of } \\
\text { recom-mended } \\
\text { self-care } \\
\text { practices with } \\
\text { special } \\
\text { emphasis on } \\
\text { high-risk } \\
\text { audience } \\
\text { segments }\end{array}$ \\
\hline Shigute,2020 & & viewpoints & - & - & - & $\begin{array}{l}\text { A good balance } \\
\text { has been } \\
\text { maintained, and } \\
\text { economic activities, } \\
\text { especially } \\
\text { agriculture and } \\
\text { industry, have } \\
\text { continued with a } \\
\text { view to maintaining } \\
\text { food security and } \\
\text { preventing unrest. }\end{array}$ & $\begin{array}{l}\text { While } \\
\text { preparatory } \\
\text { measures need } \\
\text { to continue, the } \\
\text { country's best } \\
\text { hopes lie in its } \\
\text { strategy of } \\
\text { early } \\
\text { imposition and } \\
\text { continued } \\
\text { adherence, if } \\
\text { not } \\
\text { strengthening } \\
\text { of preventive } \\
\text { measures, to } \\
\text { avoid } \\
\text { widespread } \\
\text { community } \\
\text { transmission of } \\
\text { the virus. }\end{array}$ \\
\hline
\end{tabular}




\begin{tabular}{|c|c|c|c|c|c|c|c|}
\hline Author & Affiliation & $\begin{array}{l}\text { Type of } \\
\text { research }\end{array}$ & $\begin{array}{l}\text { Site of } \\
\text { research }\end{array}$ & Participants & Instruments & Study findings & $\begin{array}{l}\text { Researchers } \\
\text { suggestions }\end{array}$ \\
\hline Bahrey,2020 & AksumUniversity & $\begin{array}{l}\text { Cross } \\
\text { sectional } \\
\text { study }\end{array}$ & & 415 ,nurses & questionnaire & $\begin{array}{l}\text { Nurses had nearly } \\
\text { three-fourth good } \\
\text { knowledge and } \\
\text { favorable attitude } \\
\text { regarding COVID- } \\
19 . \text { More than two- } \\
\text { thirds of thenurses } \\
\text { had good infection } \\
\text { prevention } \\
\text { practices towards } \\
\text { COVID-19. Nurses } \\
\text { had an almost } \\
\text { disturbed } \\
\text { psychological } \\
\text { response to } \\
\text { COVID-19. }\end{array}$ & $\begin{array}{l}\text { WHO and the } \\
\text { Ministry of } \\
\text { Health still } \\
\text { must provide } \\
\text { more } \\
\text { information for } \\
\text { better control } \\
\text { of the } \\
\text { infectious } \\
\text { disease. }\end{array}$ \\
\hline Jemal,2020 & 9 Universities & $\begin{array}{l}\text { Cross- } \\
\text { sectional } \\
\text { study }\end{array}$ & $\begin{array}{l}9 \\
\text { university } \\
\text { hospitals }\end{array}$ & $\begin{array}{l}\text { 422, health } \\
\text { workers }\end{array}$ & questionnaire & $\begin{array}{l}\text { The overall level of } \\
\text { knowledge and } \\
\text { attitude was good. } \\
\text { However, the } \\
\text { practice was } \\
\text { relatively low. } \\
\text { Source of } \\
\text { information like } \\
\text { social media, } \\
\text { telecommunication, } \\
\text { and } \\
\text { television/radio } \\
\text { were positively } \\
\text { associated with } \\
\text { healthcare workers' } \\
\text { knowledge about } \\
\text { COVID-19. }\end{array}$ & $\begin{array}{l}\text { Strategies for } \\
\text { enhancing the } \\
\text { capacity of } \\
\text { healthcare } \\
\text { workers to } \\
\text { develop } \\
\text { practice are } \\
\text { needed. }\end{array}$ \\
\hline
\end{tabular}

\section{SWOT Analysis of COVID-19 Prevention and Control Strategies in Ethiopian Higher Education}

SWOT analysis refers to the assessment and evaluation of various strengths $(S)$, weaknesses (W), opportunities (O), threats $(T)$, and other factors that influence a fight to combat COVID-19. It comprehensively, systematically, and accurately describes the scenario of COVID-19 in Ethiopian higher education. The results could help the COVID-19 taskforces to formulate the corresponding strategies, plans, and countermeasures. This method could be used to identify favorable and unfavorable factors, solve current problems in a targeted manner, recognize the challenges and obstacles faced, and formulate strategic plans to guide scientific decisions [14](Wang \& Wang, 2020).Accordingly, the strengths, weaknesses, opportunities and threats manifested in Ethiopian higher education have been summarized in the preceding section [Table 2]. 
Strengths:

- rapid response, campus shutdown, absence of face-to-face communication;

-early awareness creation on the COVID-19 preventions;

-volunteer training on COVID-19 preventions;

evaluating the activities of COVID-19 preventions;

establishing the task forces at the university level;

establishing volunteers for COVID-19 preventions;

-Research proposal development on COVID-19;

-establishing hand wash facilities;

-Production of sanitizers, face masks(Based on WHO standard);

-facilitating ICT based virtual and e-learning platforms;

- establishing exclusive COVID-19 diagnostic testing laboratories;

-health care campaigns on social media, mass media;

-COVID-19 external research collaboration;

University COVID-19 information centers;

UV apparatus development, and mechanical ventilator,

-software applications developed to facilitate risk communication;

-humanitarian support to the neighbor communities;

-virtual postgraduate graduation (Masters, Ph.D.); and

-Promoting academic staffs;

Weaknesses:

-Weak clinical research outputs;

-most Ethiopian higher education research is focused on KAP $(80 \%)$;

-unable to transact eLearning at undergraduate levels;

Inadequate infrastructure on the student's side where most students come from $80 \%$ of the rural population are living;

-unequal accessibility of teaching materials;

-lack of students motivation to participate in eLearning; and -poor technological manipulation skills (poor acculturation

of eLearning)
Opportunities:

- created a room for innovation and dissemination; -budget allocation for research on COVID-19 and related matters; -media and digital skills of instructors; researchers, leaders in the context of COVID-19;

-availability of internet except for two-weeks lockdown;

-COVID-19 task force level participation;

-internet infrastructures;

-idle human resources to mobilize on COVID-prevention health cares;

-the innovation of local UV apparatus and mechanical ventilator development funds;

- increasing humanitarian support;

-time as a resource to do different activities

-awareness creation opportunities;

-scaling up efforts to fight COVID-19;

-promoting sports activities on campus; promoting physical exercises

-low level of teaching staff load;

- availability of resources(online) and time; and

Production and economic activities to continue during the crisis.

-research call on COVID-19; and

-the publication calls on COVID-19

Threats:

-Internet outage during COVID-19 due to conflicts in Addis Ababa and Oromiya region;

-eLearning and digital communication;

-depression due to the lockdown during COVID-19

-fear of the state of emergency;

-social gatherings and movements are restricted;

-academic life disturbed due to a call at stay home;

-security, protection of COVID-19;

- lack of using consistent face mask;

-weak application and follow up of state of emergency;

- Conflicts in some part of Ethiopia prevailed shock waves of anger, resentment, and frustration throughout Ethiopia; and

-an increasing number of COVID-19 cases and deaths could be a future threat to Ethiopian higher education;

\section{Conclusion}


The Ethiopian government had a rapid response to COVID-19. The government initially established a national task force to mobilize and prevent the pandemic. It is argued that public health risk communication was effective to minimize the impact of COVID-19 during the pandemic. Ethiopian schools were shut down since March. The first important decision to safeguard school children. Following the COVID19 case report, higher education institutions banned face-to-face communication on the campuses. It was followed by shouting down oncampus educations. As a result, students were back home. Besides, the government made the highest level of risk communication by declaring a state of emergency which could also be applied to universities. The state of emergency banned all gatherings and restricted different activities. Lockdown (stay home) is the threshold of the state of emergency. In the meantime, the postgraduate program out of the campus decided and supported by e-mail and telegram has continued.

The result shows that Ethiopian higher education paved the way for the staff to research COVID-19. However, only five research were found to be published in international journals. These papers contain a majority of the research conducted on the knowledge, attitude, and perception (KAP's research) of COVID-19. The weakness of the previous research were they did not provide any clinical based attempts. However, their findings gave emphasis and suggest utilizing risk communication strategies to curb the impact of COVID-19 pandemic in Ethiopia. At this stage, no clinical research found at all. More importantly, the higher education engaged in humanitarian aid, production of sanitizers, masks, quarantine centers, and other costs of effective equipment, research, innovations during the pandemic. The adaptation of digital risk communication during meetings, postgraduate student learning, and graduation is the new organizational culture used for several months. However, due to the internet connection, there were many disruptions. The major weaknesses are weak clinical research outputs, unable to continue undergraduate education, a small number of research output relative to the huge number of academic staff and their resources. Therefore, the participation and effort of higher education to the national task force to COVID-19 preventions have been limitless. Even though huge efforts were underway, currently risk communication has at the minimal stage to the efforts to reduce the impact of COVID-19.

\section{Abbreviations}

SWOT-Strengths, Weaknesses, Opportunities, Threats

RCCE-Risk Communication and Crisis Emergency

WHO-World Health Organization

ICT-Information Communication Technology

MoSHE-Ministry of Science and Higher Education

TVET-technical and vocational education and training

HEl-Higher Education Institutions

KAP-Knowledge, Attitude and Perception

\section{Declarations}

\section{Ethics approval and consent to participate}

Not applicable

\section{Consent for publication}

Not applicable

\section{Availability of data and material}

The data used during the present study are available from the corresponding author upon reasonable request.

\section{Competing interests}

The author declare that there is no competing interest.

\section{Funding}


Not applicable

\section{Author's contributions}

MHH-contributed in data collection, methodology design, analyzing, drafting and writing the manuscript. The authors read and approved the final manuscript.

\section{Acknowledgements}

I acknowledge all data sources for this study. The major sources of the study are Ethiopian higher educations and Ethiopian Public Health Institute.

\section{Authors' information}

MHZ- is currently working as an Assistant Prof. of media, journalism and communication and a PhD candidate in media and communication. He has been working in the department of Journalism and Communications, Faculty of Humanities, Bahir Dar University, Ethiopia.

\section{References}

1. (2008). World Health Organization Outbreak Communication Planning Guide. World Health Organization. Geneva, Swetzerland: WHO.

2. Kebede,Y.,Yitayih,Y.,Birhanu,Z.,Mekonen,S., and Ambelu,A. (2020). Knowledge, perceptions and preventive practices towards COVID-19 early in the outbreak among Jimma university medical center visitors, Southwest Ethiopia. PLOS ONE, 15(5), 1-15.

3. Berry,D.C. (2004). Risk,Communication and Health Psychology. In Payne,S. \& Horn,S.(2004), Health Psychology (pp. 1-167). New York: Open University Press.

4. Walaski,P. (2011). Risk and Crisis Communications: Methods and Messages. New Jersey : WILEY.

5. (2020). Risk communication save lives and livelihoods. Global solidarity. Geneva: WHO.

6. Akalu,Y., Ayelign,B. and Derbew,M. (2020). Knowledge, Attitude and Practice Towards COVID-19 Among Chronic Disease Patients atAddis Zemen Hospital, Northwest Ethiopia. Infection and Drug Resistance, 1949-1960.

7. Khosravi,M. (2020). Perceived Risk of COVID-19 Pandemic: The Role of Public Worry and Trust. Electronic Journal of General Medicine, 17(4).

8. (2020). A Webinar on Promotion of Scientific Research in Africa. https://www.moshe.gov.et/viewNews/192. Retrieved on 20 Aug,2020.

9. Abrams,E.M. and Greenhawt,M. (2020). Risk Communication during COVID-19. Asthma \& Immunology. American Academy of Allergy.

10. Marinoni,G., Land,H.V., and Jensen,T. (2020). The impact of COVID-19 on higher education around the world: A global survey report. France: IAU.

11. Shigute,Z.,Derseh,A.,Alemu,G. and Bedi,A. (2020). Containing the spread of COVID-19 in Ethiopia. Journal of Global Health, 1-4.

12. Bahrey,D.,Tukue, G., and Teklemariam,G. (2020). Knowledge, Attitude, Practice and Psychological response toward COVID-19 among Nurses during the COVID-19 outbreak in Northern Ethiopia, 2020 . Researchsquare, 1-14.

13. Jemal et al. (2020). Knowledge, attitude and practice of healthcare workers towards COVID-19 and its prevention in Ethiopia: a multicenter study. Researchsquare, 1-14. https://doi.org/10.1371/journal.pone.0238415.

14. Wang,J and Wang,Z. (2020). Strengths, Weaknesses, Opportunities and Threats (SWOT) Analysis of China's Prevention and Control Strategy for the COVID-19 Epidemic. International Journal of Environmental Research and Public Health, 17(7), 2235. DOI: 3390/ijerph17072235.

\section{Figures}




\begin{tabular}{|l|l|l|}
\hline Listening \& responding & $\begin{array}{l}\text { Sharing information } \\
\text { to concerns }\end{array}$ & $\begin{array}{l}\text { quickly in ways people } \\
\text { trust }\end{array}$ \\
\hline
\end{tabular}

Building trust \& understanding

\begin{tabular}{|l|l|}
\hline $\begin{array}{l}\text { Engaging everyone } \\
\text { In fighting disease }\end{array}$ & $\begin{array}{l}\text { Stable economies \& } \\
\text { communities }\end{array}$ \\
\hline
\end{tabular}

Figure 1

WHO continuum of risk communication (adopted from WHO)

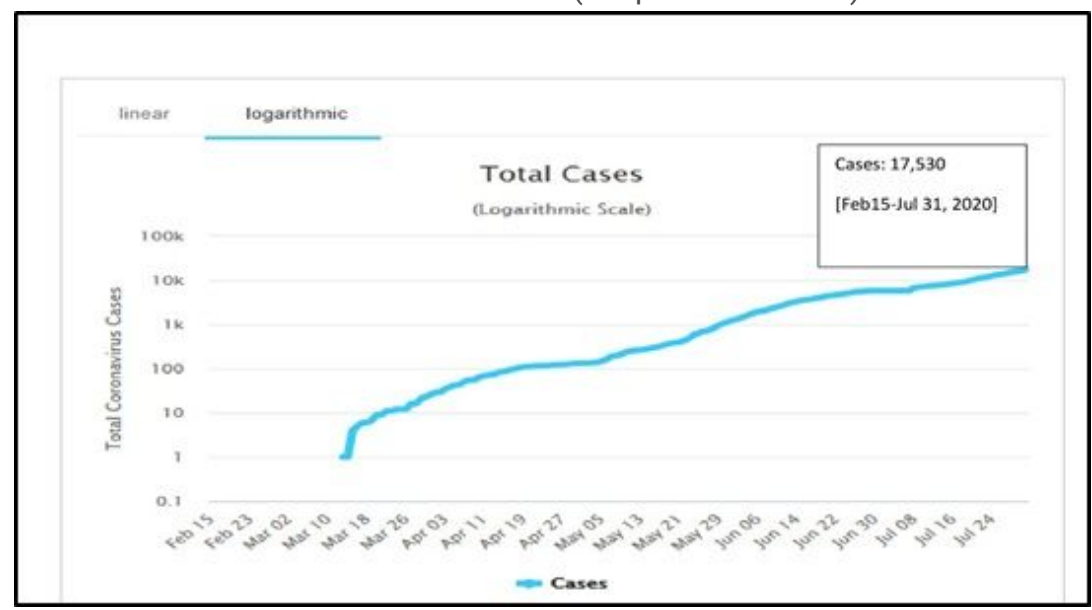

\section{Figure 2}

Total coronavirus cases in Ethiopia from Feb15-Jul31, 2020 (Source: Worldometers.info)

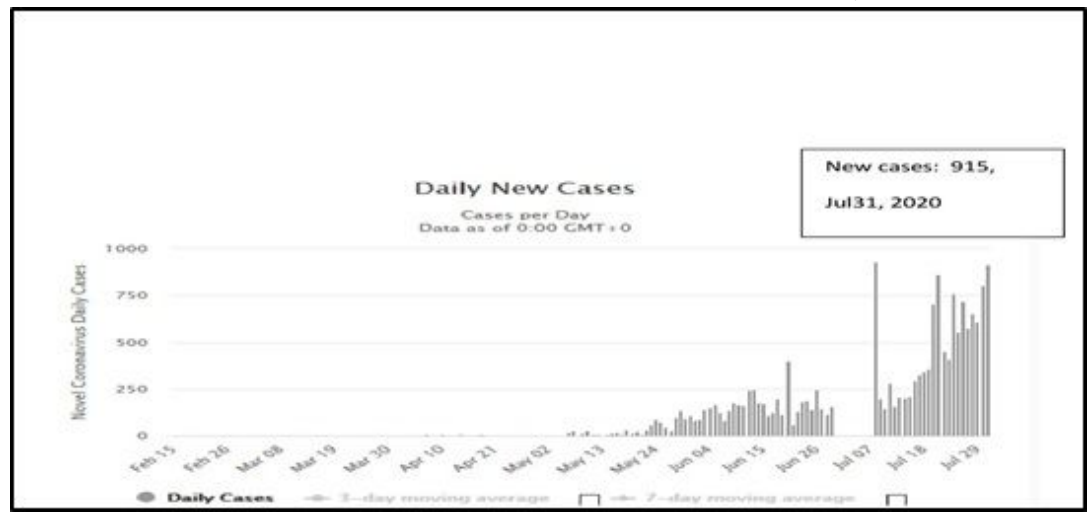

Figure 3

Daily new cases in Ethiopia (Ibid) 


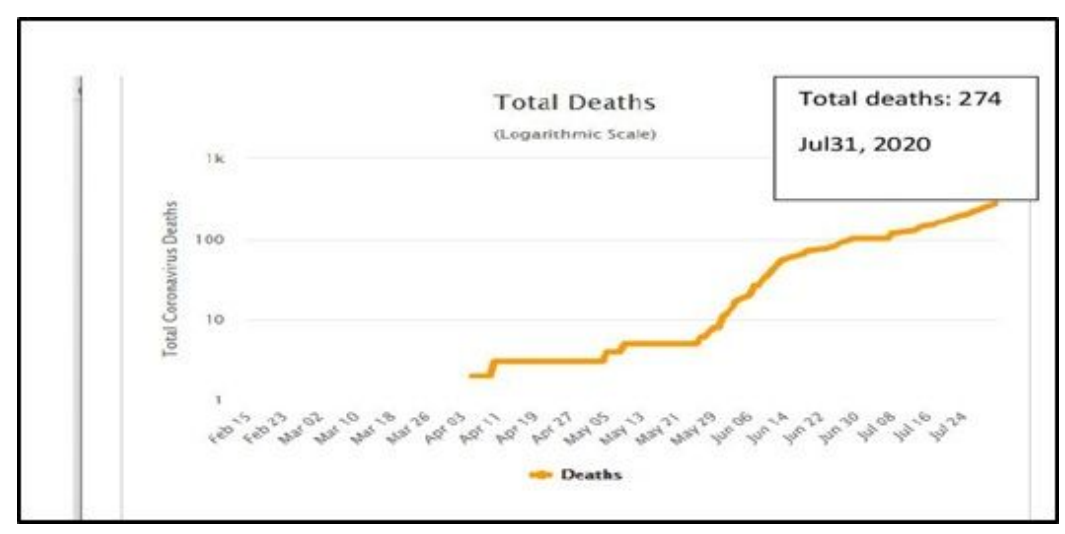

Figure 4

Total deaths in Ethiopia (Ibid)

\section{Ethiopian experience in containing COVID-19}

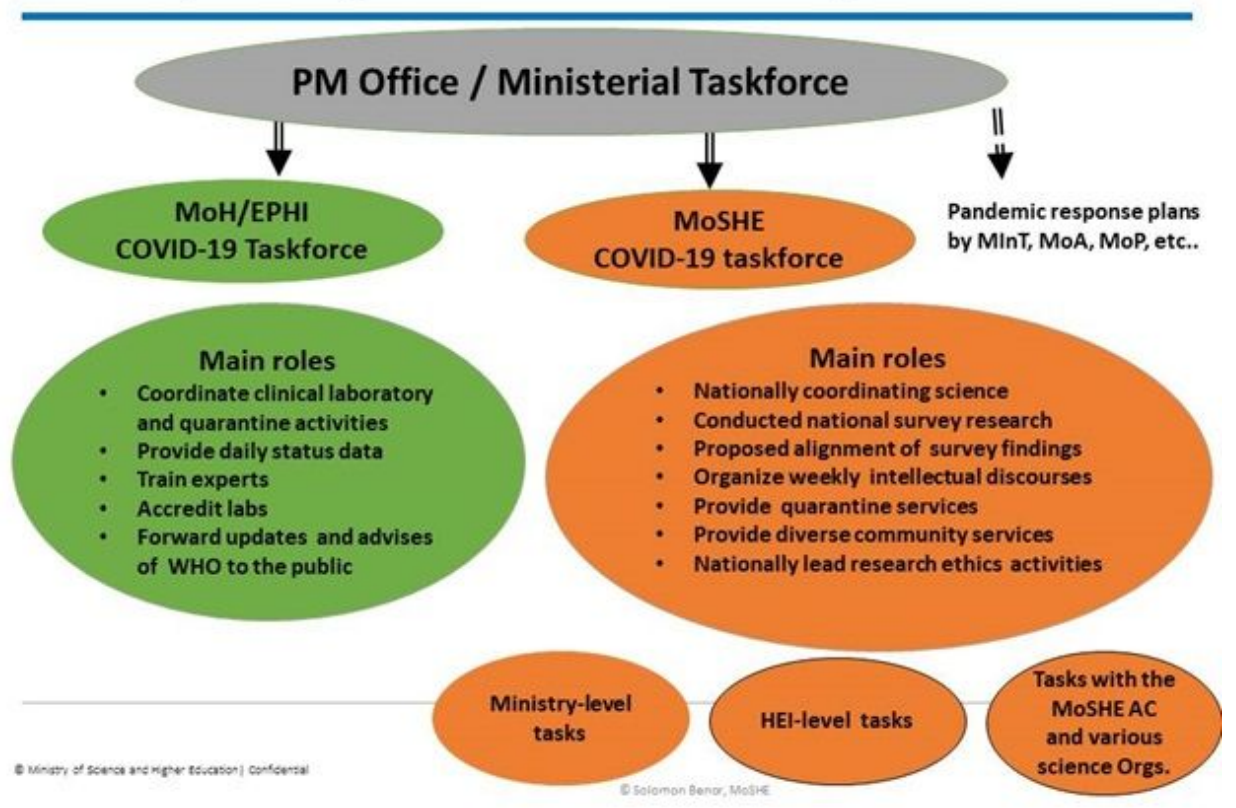

Figure 5

Risk communication hierarchical position of HEI during COVID-19 in the task force [8]

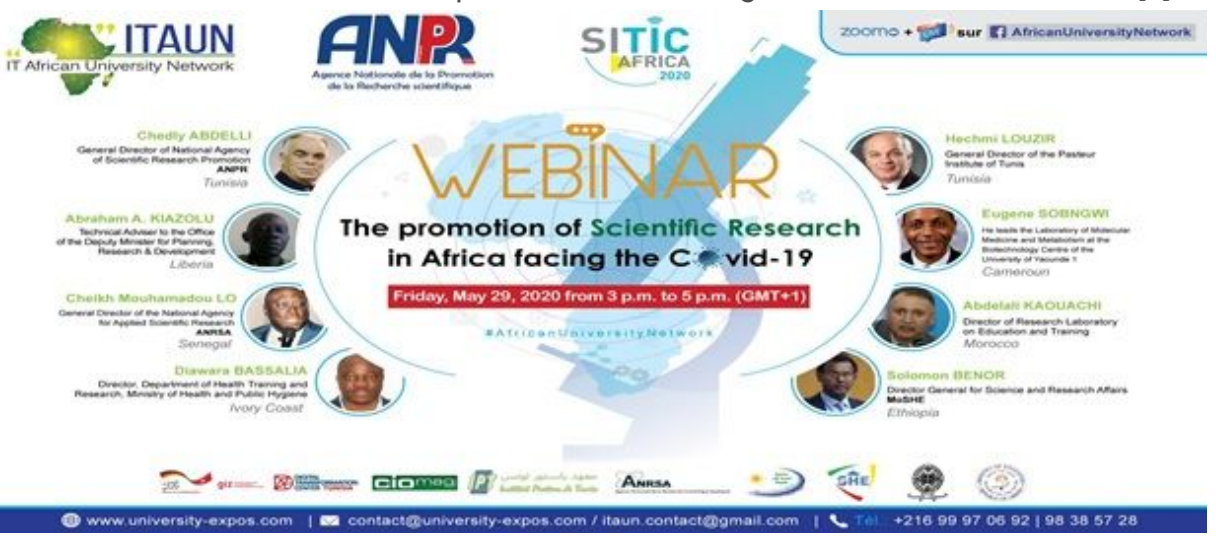

Figure 6

Risk communication of MoSHE task force during COVID-19 [8] 
Page 13/13 